\title{
Attitudes of Public Primary School Students in Jordan towards using Interactive Boards in Classroom: Empirical Study
}

\author{
Tamara Adnan Yousef Al-Smadi
}

\begin{abstract}
The present study aimed to explore the attitudes of public primary school students in Jordan towards employing interactive boards in classroom. The researcher used a descriptive analytical approach. She selected a purposive sample that consisting from 20 female and male $6^{\text {th }}$ grade students. Those students were selected from two public primary schools in Amman, Jordan. Those two schools use interactive boards in classrooms. Face-to-face interviews were conducted with those students during the first semester of the academic year (2020/2021). Descriptive statistical methods (percentages and frequencies) were used. Several results were concluded. For instance, public primary school students in Jordan have positive attitudes towards employing interactive boards in classroom.
\end{abstract}

Keywords: Attitudes, public primary school, Jordan, interactive boards, classroom.

DOI: $10.7176 / \mathrm{JEP} / 11-31-10$

Publication date: November $30^{\text {th }} 2020$

\section{Introduction}

Due to technological developments that are offered rapidly, technologies have become prevalent in various fields and institutions worldwide. For instance, it can be clear that technologies are increasingly used in educational institutions (e.g. schools, teacher training centres, and universities). In the light of the prevalence of technologies in educational institutions, the expression computer-assisted learning (CAL) emerged. This expression may be defined as the process of using computer or any other electronic device in the teaching-learning process in the aim of delivering specific information to students (Bart et al., 2013).

In the light of having increasing technologies, children today used to using computers and ICTs in their daily lives. Thus, blackboard became ineffective in classrooms. Therefore, many schools today employ interactive boards in their classrooms (Yang et al., 2012). Interactive boards were developed during the early 1990s. They are in (Schroeder, 2008). The expression (interactive whiteboard) refers to a touch-sensitive board that is connected to a computer along with a digital projector. It is employed in classrooms for displaying electronic content before students. This content can be viewed and manipulated through touching the board through using a finger or a special electronic pen (Schmid, 2006). Such boards allow teachers to navigate web pages before all students in classroom (Schroeder, 2008)

Using interactive board is deemed as a very effective teaching tool for several reasons. For instance, it enables students to think divergently. That is because the interactive board offers students the ability to make maps and diagrams and use arrows to connect ideas with each other. Thus, using this board makes lessons more organized and clearer. In addition, it plays a major role in developing students' cognition and thinking skills (e.g. specifically higher-order thinking skills). That is because the interactive board offers students the ability to conduct virtual experiments and engage in virtual experiences (Davidovitch and Yavich, 2017).

Using interactive board in classroom contributes to raising the quality of education. That is because it enables students to keep up with the latest technologies. It contributes to attracting students' attention the interactive board enable the teacher to use multimedia, various colours and manipulative features. It plays a major role in developing students' imagination. That is because the interactive board offers students the ability to see virtual things and visit places in a virtual manner (Becker \& Lee, 2009).

Using interactive board in classroom provides students with learning experiences that are deemed enjoyable (Luo and Yang, 2016). Thus, it leads to raising the degree to which students participate in learning activities in classroom. It shall encourage students to come to the board to engage in learning activities. It promotes better and deeper understanding for concepts and processes due to use of visual representation features (Kurtz et al., 2013).

Much money has been invested in employing interactive boards in educational institutions. To be specific, educational institutions invested about $4.31 \%$ billions in 2018 . It is expected that the latter amount of funds shall become 5.16 by the end of year 2023 (Al-Rabaani, 2016). Due to the increasing attention given to the use of such boards in educational institutions, the researcher believes that more studies must be conducted about such use. Hence, she aimed to explore the attitudes of public primary school students in Jordan towards employing interactive boards in classroom.

\section{The Study's Objectives}

This study aimed to

1) Identify the attitudes of public primary school students in Jordan towards using interactive boards in 
classroom.

2) Identify the advantages of using interactive boards in classrooms in public primary schools in Jordan.

3) Identify the challenges of using interactive boards in classrooms in public primary schools in Jordan.

\section{The Study's Questions}

This study aimed to answer this question:

Q.1. What are the attitudes of public primary school students in Jordan towards employing interactive boards in classroom?

Q.2. What are the advantages of using interactive boards in classrooms in public primary schools in Jordan?

Q.3. What are the challenges associated with using interactive boards in classrooms in public primary schools in Jordan?

\section{The Study's Significance}

The present study is significant because it serves as a significant reference which can be used by the researchers who want to conduct studies about the use of interactive boards. It is significant because it promotes awareness among principals, teachers and students about the advantages of using interactive boards in school classrooms. It is significant because it encourages officials in Jordan to provide teachers with training about the way of using such boards. It encourages officials to dedicate more funds for using technologies in classroom.

\section{The Study's Limits}

Temporal limits: This study was conducted during the first semester of the academic year (2020/2021). Spatial limits: This study was conducted in two public primary schools that are located in Amman, Jordan Human limits: This study targets public primary school students in Jordan.

\section{Limitations of Study}

The results can't be generalized because they are limited to the instrument, sample and spatial and temporal limits.

\section{Definition of Terms}

\subsection{Theoretical definition:}

-Interactive board: It refers to a touch-sensitive board that is connected to a computer along with a digital projector. It is employed in classrooms for displaying electronic content before students. This content can be viewed and manipulated through touching the board through using a finger or a special electronic pen (Schmid, 2006) -Attitude: It is an evaluative judgment through which one expresses the degree to which he/she prefers someone or something (Crano and Prislin, 2006, p.347).

\subsection{Operational definitions:}

-Interactive boards: They refer to the interactive boards used in classrooms in public primary school in Jordan. -Attitudes: They stand for the attitudes public primary school students in Jordan towards employing interactive boards in classroom

\section{Theoretical Framework:}

\subsection{The advantages of using interactive boards}

The use of interactive boards has a positive influence on the academic achievement of students. It leads to raising the quality of the provided education, because it lets instructors keep up with the latest development and access the latest knowledge while teaching in classroom (Thompson \& Flecknoe, 2003). Using interactive boards positively influence the students' motivation to learn and participate in academic activities. It enables the teachers to catch the students' attention in a creative manner due to the ability to use colours, and multimedia and watch films inside the classroom (Kennewell \& Beauchamp, 2007). It develops the students' capability to imaging, because it lets the students engage in virtual experiences and visits various far places virtually. It promotes creativity among students, because it enables students to manipulate and adjust the e-content as they desire (Becker \& Lee, 2009). Such boards can be effectively used for improving students' achievement in language and math courses. Using those boards improve the reading skills of students, because they offer text-to-speech features. Thus, it is necessary to use such boards in language classrooms of the first three grades (López, 2010).

The use of interactive boards contributes to the development of the higher order thinking skills, due to the capability of implementing knowledge in a virtual manner. It increases the interaction in classroom, because it offers a rich content that increase the opportunities to engage in discussion (Blau, 2011). It improves students writing skills (Albaaly and Higgins, 2011). It offers numerous learning opportunities for students in science, technology, engineering, and math courses (STEM courses). It also offers many opportunities to learn language(s) and develop language skills. That is because students can interact with native speakers and contact experts in the 
field of linguistics and language teaching to learn from them. It is because using interactive boards lets students access, and navigate numerous bilingual and monolingual dictionaries and books in classroom (Shi et al., 2012). The use of interactive boards plays a significant role in having the students' problem solving and critical thinking skills improved. That is because such boards lets the students see things that he has never seen before and think about them (i.e. volcanos). The use of interactive boards contributes to the promotion of collaboration and cooperation among students. That's because students shall feel encouraged to collaborate with each other when having a game. The use of interactive boards turns students into active learners. That is because using such boards motivates students to engage in the enjoyable learning activities (Shi et al., 2012).

The use of interactive boards leads to promoting innovation. That is because such use enables students to come up with new designs and construct new knowledge by themselves. Such use enhances the extent of understanding information in mathematics. Interactive boards are widely used due to their beneficial features. For instance, the software that is usually provided with such boards include several features, such as:

a) Providing a great size of storage. This software enables teachers to have the material retrieved quickly. Thus, the use of such boards facilitate the process of revising previous information in classroom.

b) Employing animation

c) Manipulation objects and items

d) Presenting multimedia through the use of a projector

e) Using numerous colours, and shades and highlighting words

f) Employing the hide \& reveal feature and the drag and drop one (De Vita et al., 2014).

It turns learning activities into fun activities and turns students' attitudes towards learning into positive ones (Luo and Yand, 2016). It leads to fostering the students' cognitive development of students. It enables students to save time because it enables them to access information fast. It increases the teachers' productivity, because it offers numerous. It provides teachers' with various references and sources of information. Thus, it expands teachers' knowledge and develops them professionally (Alshaikhi, 2017).

According to Alshaikhi (2017), the use of interactive boards leads to turning the learning environment into an environment that's based on cooperative work. It enables teachers to dedicate less time and effort for the lesson preparation due to the ability of accessing various. That is because teachers can download materials from the internet to present them in classroom. It leads to attracting students' attention effectively. It enables teachers to develop their instructional approaches. That is because integrating technology with instructional approaches shall improve such approaches (Alshaikhi, 2017).

According to Dori \& Kurtz (2015), using interactive boards promotes a better understanding for the academic material being taught. It contributes to expanding students' knowledge and enables students to construct knowledge by themselves. It enables teachers to present the information in a well-organized manner. It improves students' efficiency in learning. It provide students with an access to a variety of tools and promote a sense of creativity within students (Dori \& Kurtz, 2015).

\section{Empirical Studies}

The researcher reviewed several studies which are shown below. Those studies are ordered based on the year of publication:

\subsection{The advantages of using interactive boards}

Kurtz et al. (2013) aimed to explore the advantages and disadvantages of using interactive boards in primary schools in Israel. He collected data through employing a questionnaire. The sample consists from sixteen teachers who were selected from a primary school located in Israel. Regarding advantages, using such boards make students interested in the learning process and curious and motivated to learn. It contributes to documenting the material. That's because the lesson material and the teachers' comments can be saved in files to be shared later with students. Using such boards lets the teacher illustrate the information in a better manner due to using multimedia features (i.e. videos and images). Regarding disadvantages, teachers need to dedicate much time for preparing for the lessons involving the use of such boards. That is because teachers need to create an electronic content. In addition, some teachers aren't capable to use interactive boards effectively, because they weren't provided with extensive training. Teachers face sometimes technical problems while using such boards (Kurtz et al., 2013)

Alfahadi (2015) aimed at investigating the degree to which using interactive boards is effective in teaching English language to EFL university students at Tabuk University during the preparatory year. The selected sample consists of thirty six students. Those students were chosen in a random manner. A pre-test and a post-test were administered. A survey was employed for exploring the selected students' attitudes. The survey was administered after administering the tests. Several findings were concluded. For instance, using those boards has a significant positive impact on the achievement of the EFL students. Thus, it is effective in language courses. It enhances the attitudes of students towards the course and the process of learning English language. It makes the students feel encourages and motivated to learn English. It motivates students to dedicate more time on reading e-books that 
are drafted in English. That is because such boards add interactive features to e-books.

Cakiroglu (2016) aimed to investigating the secondary school teachers' attitudes towards the use of interactive boards in the process of teaching secondary school students. The sample consists from 142 teachers. It includes English language, math, and science teachers. Data was obtained from those teachers those the use of a questionnaire. Several findings were concluded. For instance, the use of such boards leads to improving students' academic achievement. It leads to motivating students to learn and increasing their interaction with their teachers. It enhances the extent of understanding the material and promotes creativity among them. It enables students to access and review the material presented earlier easily. It turns the learning process into an enjoyable process. It makes the information being presented in the lesson well-organized.

Davidovitch and Yavich (2017) aimed to explore the impacts of using interactive boards on primary school students' motivation and cognition in Palestine. They selected a sample that consisting from 130 primary school students. Those students were chosen from Jerusalem. Data was collected through a questionnaire. Several findings were reached. For instance, using interactive boards improves primary school students' motivation to learn, concentration, and cognition. It increases the satisfaction of those students with the teaching-learning process. It makes lessons clearer and more organized.

Demir and Tunaboylu (2017) aimed to investigating the influence of use of interactive boards on achievement in math among students in the lower secondary schools. The sample involves fifty eight students. Those students are seventh grade students. They are divided into control group and experimental one. Experimental approach is adopted. Pre-test and post-test are used. Through data analysis, the researchers concluded that the use of interactive boards shall positively affect the achievement in math of students in the lower secondary schools. The latter use shall positively affect the problem solving skills of students. It shall positively affect the ability to solve equation.

Aldhafiri (2020) aimed to explore the effectiveness of using interactive white boards in improving the Arabic listening skills of the undergraduates who are majoring in Arabic language at Kuwaiti universities. He selected a purposive sample consisting from 60 male undergraduates who are majoring in Arabic language at Kuwait University. SPSS software was employed for data analysis. It was found that using interactive white boards has a positive impacts on students' academic achievement in Arabic language listening exams. In addition, using such boards contributes to improving the targeted skills.

\subsection{The challenges associated with using technology in educational institutions}

Aldhoon et al. (2010) aimed at exploring the obstacles hindering the use of e-learning system in secondary schools in Al-Kourah District, Irbid, Jordan. They aimed to shed a light on obstacles related to administration, teachers, students, infrastructure \& equipment. A thirty-six-item questionnaire was employed by those researchers. Data was obtained from 47 male teachers and 58 female teachers. Scheffe test and three-way analysis of variance were conducted. The researchers found that the severity of the obstacles hindering the use of e-learning system in secondary schools in Al-Kourah District is high in all the areas jointly and separately. The teachers-related obstacles include: the teachers' lack of motivation to use the e-learning system. In addition, the teachers' low English proficiency level which hinders them from using this system. Some teachers have low computer literacy level that hinders them from such use (Aldhoon et al., 2010)

The admiration-related obstacles include: assigning many tasks to the teachers which hinders them from using the e-learning system. They include: the lack of awareness among administrators about the significance of using technology. They include: providing teachers with inadequate training. They include: providing teachers with inadequate financial incentives for encouraging them to use this system. The obstacles related to infrastructure \& equipment include: having poor internet connection, and inadequacy of the maintenance services, and e-content. The students-related obstacles include: having a great number of students in classroom and having students whose computer literacy level is low. Some students show resistance to the use of the e-learning system (Aldhoon et al., 2010).

Zeedan (2015) aimed at identifying the problems that are associated with the use of technology in preparatory schools at AL-Ramadi, Iraq from the perspective of Arabic language teachers. He aimed to shed a light on the problems associated with teachers, students and the school environment. He used a questionnaire which involves thirty six items. He collected data from 88 female and male teachers. Those teachers were selected through the simple random method. T-test is conducted and Pearson correlation coefficient values are calculated. Several results are reached. For instance, the severity of the problems that are associated with the use of technology in in preparatory schools at AL-Ramadi, Iraq is high. The problems related to the school environment include: the lack of the programs used in Arabic language, inadequate maintenance services, having too many students in classroom, facing many technical problems while using the computers and financial challenges (Zeedan, 2015).

The problems related to the teachers include: having teachers who have poor time-management skills while using technology in classroom. They include: having teachers who have resistance to using modern technologies. They include: having teachers who aren't capable to use technology effectively due to lack of training courses. They include: having teachers who aren't capable to manage classroom effectively while using technology in 
classroom. They include: having poor awareness among teachers about the significance of using technology in classroom. The problems related to the students include: having students who aren't motivated to use technology in classroom (Zeedan, 2015).

\section{Methodology}

9.1. Approach

The researcher used a descriptive analytical approach

\subsection{Population and Sample}

The population is represented in all the public primary school students in Jordan. She selected a purposive sample that consists of 20 female and male 6th grade students. Those students were selected from two public primary schools in Amman, Jordan. Those two schools use interactive boards in classrooms. Face-to-face interviews were conducted with those students during the first semester of the academic year (2020/2021). Information about the sample is shown below.

\begin{tabular}{|l|l|l|l|}
\hline Variable & Category & Frequency & Percentage \\
\hline \multirow{2}{*}{ Gender } & Males & 10 & 50 \\
\cline { 2 - 4 } & Females & 10 & 50 \\
\hline
\end{tabular}

$\mathrm{N}=20$

\subsection{Data collection method}

The researcher conducted interviews with 20 female and male 6th grade students. Those students were selected from two public primary schools in Amman, Jordan. Those two schools use interactive boards in classrooms. The interviews consist from the questions shown below. The first and second questions of the interview questions are yes/no questions.

Q.1. Do you believe that using interactive boards plays an effective role in improving the quality of school education?

Q.2. Are you satisfied with your experience in using interactive boards in classroom?

Q.3. What are the advantages of using interactive boards in classroom?

Q.4. What are the challenges associated with using interactive boards in classrooms?

\subsection{Validity of the Instrument}

The researcher passed the question sheet of the interview to two experts who are considered specialized in the field of instructional technology. Those experts work in a well-known Jordanian university as faculty members. They suggest that the interview questions enable the researcher to meet the intended goals. They suggest that the interview questions can be easily understood by the interviewees.

\subsection{Data analysis}

The researcher analysed the respondents' answers in the interview. She also used descriptive statistical methods to answer the first and second questions of the interview questions. The latter methods are represented in frequencies and percentages.

\section{Results and Discussion}

\subsection{Results and discussion related to the study's first question}

Q.1. What are the attitudes of public primary school students in Jordan towards employing interactive boards in classroom?

18 students $(90 \%)$ believe that using interactive boards plays an effective role in improving the quality of school education. This result is consistent with what's suggested by Becker \& Lee (2009). It is because such use lets the students access any piece of information they want in classroom. It indicates that the Jordanian Ministry of Education implemented effective plans for using such boards in classrooms in public schools. 18 students $(90 \%)$ are satisfied with their experience in using interactive boards in classroom. This result is in agreement with the one concluded by Davidovitch and Yavich (2017). It indicates that the Jordanian Ministry of Education succeeded in employing such boards for delivering school education. The latter results indicates that the respondents hold positive attitudes towards employing interactive boards in school education.

\subsection{Results and discussion related to the study's second question}

Q.2. What are the advantages of using interactive boards in classrooms in public primary schools in Jordan?

[1] Using interactive boards is motivational:

11 students suggest that using interactive boards in classroom motivates them to learn and acquire more information and knowledge. This result is consistent with what's suggested by Luo and Yang (2016). It is because 
using such boards enables students to go in virtual trips and discover new things without having to travel to far place nor dedicate much money. It is because using such boards enables students to use manipulate the electronic content and engage in electronic games. . For instance, a student said: 'Using interactive board in classroom makes more motivated to learn about science, arts, languages, and etc.. ',

[2] Improving language skills

4 students suggested that using such boards in classroom improves students' language skills. This result is in agreement with the finding reached by Alfahadi (2015). It is because such boards let students check online dictionaries and navigate books including language-related information. It's because such boards include text-tospeech features. . For instance, a student said: 'Using interactive board in classroom enables me to hear the pronunciation of a word within a few seconds".

[3] Using interactive boards improves academic achievement

7 students suggest that using interactive board in classroom improves their academic achievement. This results is in agreement with the one reached by Aldhafiri (2020). That is because using interactive board offers students the opportunity to see applications for the knowledge they have acquired. That contributes to promoting deep learning. [4] Presenting the material in a well-organized manner

9 students suggest that using such boards in classroom makes the material more organized. This result is in agreement with the one concluded by Davidovitch and Yavich (2017). That's because using such boards enables teachers to organize the material into various files and use maps, and diagrams for categorizing information. For instance, a student said: 'Using interactive board in classroom enables my teachers to organize the material into various files on a flash memory instead of carrying out numerous papers and books ".

[5] Promoting creativity

3 students suggested that that using such boards in classroom promotes creativity among students. This result is in agreement with what's added by Dori \& Kurtz (2015). It is because such boards enable students to come up with creative ideas, designs and solutions. For instance, a student said: 'Using interactive board in classroom makes more creative. For instance, the images and videos presented on this boards makes me come up with original ideas, ,

[6] Increasing concentration

5 students suggested that using such boards improves students' concentration. This result is in agreement with the one concluded by Davidovitch and Yavich (2017). That's because such boards enable teachers to use attractive colours and audio and visual features and animation. Such use shall attract students' attention and make them highly like using technology and in learning. Thus, they student shall be highly concentrated. For instance, a student said: 'Using interactive board in classroom makes me highly focused. I don't know why. It may be attributed to the use eye catching colours",

[7] Learning become enjoyable and attitudes towards learning become positive

8 students suggested that using such boards make learning a fun, interesting and enjoyable process. This result is in agreement with what's added by Luo and Yang (2016). It is because using such boards let students engage in instructional games and use the internet. For instance, a student said: 'Using interactive board in classroom makes learning fun, and enjoyable. It is really boring to learn without using this board'.

5 students suggested that using such boards leads to promoting positive attitudes towards the process of learning. This results is in agreement with what's added by Luo and Yand (2016). This is because the interactive features turn the learning process into an enjoyable process that students like rather than a process that's based on the spoon-feeding method learning method.

[8] Improving thinking

3 students suggested that using such boards improves students' thinking. This result is in agreement with what's added by Blau (2011). It is because using such boards lets the students see things that they haven't seen before. It's because using such boards offers the students the opportunity to address virtual problems.

\subsection{Results and discussion related to the study's third question}

Q.3. What are the challenges associated with using interactive boards in classrooms in public primary schools in Jordan?

[1] Teachers' poor English proficiency level

5 students suggested that some teachers have poor English proficiency level. This result is in agreement with the once reached by Aldhoon et al. (2010). Therefore, the Ministry of Education in Jordan must provide teachers with more courses for improving their English proficiency levels.

[2] Teachers' resistance to use such boards

6 students suggested that some teachers resist the use of such boards. This result is in agreement with the once reached by Zeedan (2015). It is because some school principals don't promote awareness among teachers about the significance of using boards. Thus, officials in the Jordanian Ministry of Education must encourage school principals and administrators to promote such awareness among teachers. For instance, a student said: '’Some 
teachers use the board for few minutes during the period".

[3] Teachers' poor computer literacy level due to poor training:

8 students suggested that some teachers have poor skills in using computer. This result is in agreement with the once reached by Aldhoon et al. (2010). It's attributed to the inadequate training provided for those teachers. Therefore, the Ministry of Education in Jordan must provide teachers with more courses about the way of using technology.

[4] Poor internet connection

7 students suggested that the internet connection is poor. This result is in agreement with the once reached by Aldhoon et al. (2010). Thus, the Ministry of Education in Jordan must address this problem through making contracts with companies that provide excellent internet services. One of the sampled students said: 'The major challenges faced in using such boards are represented in having the internet connection disconnected during the period",

[5] Technical problems

4 students suggested that technical problems are faced sometimes during the period. This result is in agreement with the once reached by Kurtz et al. (2013). Thus, the Ministry of Education in Jordan must provide more attention to the maintenance services. It must seek purchasing the latest advanced e-learning systems.

\section{Conclusion}

Through analysing the answers of the students, the researcher concluded several findings. For instance, of public primary school students in Jordan have positive attitudes towards using interactive boards in classroom. They believe that using such boards shall improve the quality of school education, because it lets them keep up with the latest trends and developments. It is because such use lets the students access any piece of information they want in classroom. In addition, public primary school students in Jordan are very satisfied with their experience in using interactive boards in classroom. Such high satisfaction is attributed to implementing effective plans by the Jordanian Ministry of Education for using such boards effectively

Regarding the advantages of using interactive boards in Jordanian public primary schools, they include motivating students, raising their academic achievement and improving their thinking and language skills. They also include: Presenting the material in a well-organized manner and promoting creativity. They include: increasing the students' level of concentration. They include: turning the learning process into an enjoyable and fun process that students like.

Regarding the challenges associated with using interactive boards in Jordanian public primary schools, they include having teachers of low computer literacy level. They include: having teachers of low English proficiency level. Such low levels are attributed to the inadequacy of the training courses provided for those teachers. The challenges associated with such use include: the teachers' resistance to such use and the poor internet connection.

\section{Recommendations}

The researcher recommends:

-Providing teachers in Jordanian public schools with training courses about the way of using interactive boards -Providing teachers in Jordanian schools with courses about the teaching strategies that should be employed when using such boards in classroom

-Making an electronic version for each school curriculum in Jordan. That shall enable teachers to present the content of the curricula easily.

\section{Suggestions for Researchers:}

The researcher recommends:

Conducting studies about the effectiveness of using interactive boards in raising students' academic achievement and retention of concepts

- $\quad$ Conducting studies about the effectiveness of using interactive boards in each school course (e.g. science, language, and history courses)

- $\quad$ Conducting studies about the effectiveness of using interactive boards in universities and teacher training centres.

References:

Albaaly, E. and Higgins, S. (2011). The impact of interactive whiteboard technology on medical students' achievement in ESL essay writing: An early study in Egypt. Language Learning Journal. 40(2), p207-222, DOI: $10.1080 / 09571736.2010 .543953$

Aldhafiri, M.D (2020).. The effectiveness of using interactive white boards in improving the Arabic listening skills of undergraduates majoring in Arabic language at Kuwaiti universities. Educ Inf Technol. Issue No. 25, 3577-3591. https://doi.org/10.1007/s10639-020-10107-5 
Aldhoon, M.; Muflih, M.; and El-Hersh, A. (2010). Obstacles of the Application of E-Learning Systems as Viewed by Secondary School Teachers at Al-Kurah District. The Jordanian Journal for Educational Sciences. 6(1), $27-40$

Alfahadi, A. (2015). The effectiveness of using smart board technology in teaching English as a foreign language to preparatory year students at Tabuk University. Education Journal. 4(6). 332-337, doi: $10.11648 /$ j.edu.20150406.12

Al-Rabaani, A.H. (2018). Social studies teachers' perspectives on the advantages and challenges of interactive whiteboard application in Oman. European Journal of Educational Research, 7(4), 753-762. doi:10.12973/eu-jer.7.4.753. DOI: 10.12973/eu-jer.7.4.753

Alshaikhi, M. (2017). Investigating teachers' attitudes towards the effectiveness of using interactive whiteboards when teaching English as a foreign language. Journal of Modern Education Review, 7(3), pp. 210-219, Doi: 10.15341/jmer(2155-7993)/03.07.2017/007

Bart, S.; Yasin, M.; and Ramli, M. (2013). Computer-Assisted Teaching and Learning among Special Education Teachers. Asian Social Science, 9(16), 87-94, doi:10.5539/ass.v9n16p87

Becker, C., \& Lee, M. (2009). The interactive whiteboard revolution: Teaching with IWBs. Victoria, Australia: ACER Press

Blau, I. (2011). Being a smart teacher in a "smart classroom": Assessing teacher professional development for incorporating Interactive White Boards at schools. Learning in the Technological Era, 63-74

Cakiroglu, O. (2016). Teachers and students views on the use of IWBs in secondary schools for enhancing classroom teaching and learning. The Journal of the Faculty of Education at Dicle University. Issue No. 29, p.374-386, DOI: http://dx.doi.org/10.14582/DUZGEF.1798

Crano, W. D., \& Prislin, R. (2006). Attitudes and persuasion. Annual Review of Psychology, Vol. 57, p. 345 - 374 , https://doi.org/10.1146/annurev.psych.57.102904.190034

Davidovitch, N. and Yavich, R. (2017).The Effect of Smart Boards on the Cognition and Motivation of Students. Higher Education Studies, 7(1), 60-68, doi:10.5539/hes.v7n1p60

Demir, E. and Tunaboylu, C. (2017). The effect of teaching supported by interactive whiteboard on students' mathematical achievements in lower secondary education, Journal of Education and Learning, 6(1), 81-94. Doi:10.5539/jel.v6n1p81

De Vita, Mauro; Verschaffel, Lieven \& Elen, Jan. (2014). Interactive whiteboards in mathematics teaching: A literature review. Education Research International. Vol. 2014, p. 1-16. DOI: 10.1155/2014/401315.

Dori, S., \& Kurtz, G. (2015). Student's perceptions meaningful learning via ICT. The proceedings of a conference titled (Chais Annual Meeting). This conference was held in 2015 in the Open University at Raanana.

Kennewell, S., \& Beauchamp, G. (2007). The features of interactive whiteboards and their influence on learning. Learning, Media, and Technology, 32(3), 227-241. http://dx.doi.org/10.1080/17439880701511073

Kurtz, G.; Kochavi, E.; and David, K. (2013). Teachers' Perceptions of the Use of the Interactive Whiteboard and its impact on Their Self-Perceptions as ICT Literate. Journal of Modern Education Review, 3(2), 155-161

López, Omar. (2010). The digital learning classroom: improving English language learners' academic success in mathematics and reading using interactive whiteboard technology. Computers \& Education. 54. 901-915. 10.1016/j.compedu.2009.09.019.

Luo, Y.; and Yand, S. (2016). The effect of the interactive functions of whiteboards on elementary students' learning. Journal of Educational Computing Research. 54(5), 680-700, https://doi.org/10.1177\%2F0735633115628032

Mathews-Aydinli, J. \& Elaziz, F. (2010). Turkish students' and teachers' attitudes toward the use of interactive whiteboards in EFL classrooms. Computer Assisted Language Learning. 23(3). 235-252. 10.1080/09588221003776781.

Shi, Y.; Yang, Z.; Yang, H.; and Liu, S. (2012). The impact of interactive whiteboards on education. The Proceedings of the 7th International Conference on Internet Multimedia Computing and Service. China.

Schmid, E. (2006). Using a voting system in conjunction with interactive whiteboard technology to enhance learning in the English language classroom. Computer and Education, 50, 338-356

Schroeder, R. (2008). Active learning with interactive whiteboards: A literature review and a case study for college freshmen. Communications in Information Literacy: 1(2). DOI: 10.15760/comminfolit.2008.1.2.10

Thompson, J., \& Flecknoe, M. (2003). Raising attainment with an interactive whiteboard in Key Stage 2. Management in Education, 17(3), 29-33. http://dx.doi.org/10.1177/08920206030170030601

Yang, Kai-Ti; Wang, Tzu-Hua and Kao, Ying-Chen (2012). How an interactive whiteboard impacts a traditional classroom. Education as Change. 16 (2),p. 313- 332.

Zeedan, N. (2015). The Problems of using technology in education encountering Arabic language teachers in preparatory stage at AL- Ramadi city in Iraq from teachers point of view. Published MA thesis. The Middle East University. Jordan 